\title{
Land-use regime shifts: an analytical framework and agenda for future land- use research
}

Navin Ramankutty ${ }^{1,2}$ and Oliver T. Coomes ${ }^{3}$

\begin{abstract}
A key research frontier in global change research lies in understanding processes of land change to inform predictive models of future land states. We believe that significant advances in the field are hampered by limited attention being paid to critical points of change termed land-use regime shifts. We present an analytical framework for understanding land-use regime shifts. We survey historical events of land change and perform in-depth case studies of soy and shrimp development in Latin America to demonstrate the role of preconditions, triggers, and self-reinforcing processes in driving land-use regime shifts. Whereas the land-use literature demonstrates a good understanding of within-regime dynamics, our understanding of the drivers of land-use regime shifts is limited to ex post facto explications. Theoretical and empirical advances are needed to better understand the dynamics and implications of land-use regime shifts. We draw insights from the regime-shifts literature to propose a research agenda for studying land change.
\end{abstract}

Key Words: land-cover change; land-use change; Latin America; modeling; prediction; regime shifts

\section{INTRODUCTION}

An important challenge facing global change science is the prediction of future states of land cover (Veldkamp and Lambin 2001). Land use and cover change is a major cause of global environmental change (Foley et al. 2005), and models that assess future states of the Earth system typically incorporate a landcover change component. Predictions of future land cover are central to scenario building (e.g., Alcamo et al. 2009) for global climate science (e.g., Feddema et al. 2005), global ecosystem assessments (e.g., Alcamo et al. 2005), and regional ecosystem service trade-off evaluations (e.g., Nelson et al. 2009).

In the drive for increased predictive capability, many researchers are seeking to understand the dynamics of land-use change (Lambin and Geist 2006, Rounsevell et al. 2012, Müller and Munroe 2014). Authoritative works on long-term trajectories of land-use change include William Cronon's (1983) exploration of changing human-landscape interactions following colonization of New England, Warren Dean's (1995) accounts of the destruction of the Brazilian Atlantic forest, Donald Worster's (1979) environmental history of the North American dustbowl of the 1930s, and Madhav Gadgil and Ramachandra Guha's (1993) ecological history of India. In the last two decades, a rapidly expanding literature reports on monitoring and understanding of more recent land use and cover change. Indeed, a search for the key words "land use" or "land cover" in the title of journal articles in the Scopus database reveals a 20-fold increase from 207 articles in 1990 to 4499 in 2015.

A large number of case studies point to the complex and contextual place-specific nature of human-environment relationships that drive changes in land use and land cover. Recent meta-analytic studies have found that land-use change is driven by a rich array of factors operating at multiple scales (e.g., Keys and McConnell 2005, Lambin and Geist 2006). Emerging ideas such as: forest transition, land-change syndromes, land teleconnections, and telecoupling have been important to our broad understanding of land use and cover change (Lüdeke et al. 2004, Rudel et al. 2005, Geist et al. 2006, Seto et al. 2012, Friis et al. 2016).

We argue that critical land-use changes often occur abruptly, in fits and starts, as a punctuated equilibrium process, in which regime shifts are of critical importance (Ramankutty 2007, Lambin and Meyfroidt 2010, Ramankutty et al. 2010, Müller et al. 2014). Under a given land-use regime, land-use dynamics are relatively stable and evolve slowly and often predictably for long periods; but then the enduring land-use dynamics abruptly shift as a new microfoundational logic that guides land use develops, and a new land-use regime is established, therefore, a land-use regime shift has occurred. We posit that land-use regime shifts are important elements of land change, often unpredictable, and resulting in rapid and extensive land-cover changes on the time scales of relevance to the global change community. Limited research to date has sought to understand such shifts (but see Müller et al., 2014); most have focused on understanding the landuse dynamics within a given land-use regime, say cattle ranching in Amazonia or oil palm production in SE Asia, without considering how a particular land-use regime is established in the first place (Fearnside 2005, Pontius et al. 2008, Kongsager and Reenberg 2012).

Motivated by these general observations, we argue that more attention is needed to study the drivers of land-use regime shifts. An improved understanding of land-use regime shifts can help better anticipate future land-use change. And, even if prediction is impossible, because many land-use regime shifts are driven by external (exogenous) events (e.g., policy change, price shocks, wars, etc.) and such events are difficult to predict (Müller et al., 2014), an improved theoretical framework and a clearer understanding of system dynamics could help identify system vulnerabilities to regime shifts. This will greatly aid the

\footnotetext{
${ }^{1}$ Liu Institute for Global Issues, ${ }^{2}$ Institute for Resources, Environment, and Sustainability, University of British Columbia, ${ }^{3}$ Department of
} Geography, McGill University 
development of future scenarios of land-use change that could be sensitive to our understanding of system vulnerabilities given various assumptions about external shocks to the system.

\section{LOOKING BACK TO LOOK FORWARD: TWO HISTORICAL CASES}

One of the significant achievements of the land-change community over the last decade has been the development of global historical time series of land cover (Ramankutty and Foley 1999, Klein Goldewijk 2001). Although such reconstruction is often based on interpolations between limited data points or estimates based on proxy information (tax records, population), more reliable data or reconstructions are available for some countries. We used available historical data on cultivated area for Argentina and the former Soviet Union over the 20th century to explore historical drivers of some of the most significant historical land changes (Figs. 1A, 1B).

European settlement of Argentina began with the founding of Buenos Aires in 1580 with settlers occupying a narrow strip along the coast south of Buenos Aires (Solbrig and Viglizzo 1999). The main agricultural activity was raising livestock for export with some grain and vegetable farming for supplying urban markets. The gradual expansion of livestock raising during the $1800 \mathrm{~s}$ brought settlers into conflict with the native tribes; a conflict that lasted for almost 80 years. The Argentine army opened the Pampa for settlers in 1879. The introduction of forage crops, followed by immigrant tenants to cultivate these, brought about a sea change in Argentine agriculture (Taylor 1997). From 1880 onward, grain production developed, mainly in the Pampa, with the cultivation of wheat, corn, and flaxseed initially, followed by other small grains (Fig. 1A). Argentine economic output indicators during the early 1900 s were comparable to other developed nations. This was accompanied by a wave of European immigration and foreign direct investment (Smith 1968, Rudbeck 1970). However, Argentine exports of grain decreased during World War I, caused by a shortage of access to ocean shipping (Rudbeck 1970). It recovered rapidly during the 1920s but then slumped again after the Great Depression hit in 1929, which was soon followed by World War II. Argentina became one of the world's largest grain exporters, accounting for over one-third of international grain trade just prior to World War II. Cultivated area in Argentina followed the swings dictated by these world events, with a steep rise between 1900 and 1910 during the development of the Pampa, subsequent plateau during World War I, increase again in the 1920s, and then a plateau again following the Great Depression (Fig. 1A). The dramatic increase in cultivated area since 1995 is a result of the massive, well-known expansion of soybeans (Grau et al. 2005).

Changes in cultivated area in the former Soviet Union over the last century, based on several statistical sources, are shown in Figure 1B. The influence of the two world wars on decreasing sown area, and subsequent recovery, is apparent. However, these decreases could partly be a result of changes in political boundaries. For example, during the German occupation of 1941-44, which happened during the peak of collectivization in the Soviet Union, the Germans occupied almost 50 percent of the most productive land, or 44 percent of the total number of collective farms in 1940 (Katkoff 1950). By 1950, total sown area seems to have recovered to the 1940 level. In 1954, Khrushchev introduced the Virgin Lands Program to increase Soviet grain production by ploughing up vast areas of virgin and fallow land in Kazakhstan, Siberia, the Urals, and the north Caucasus (Durgin 1962). Total sown area increased by 46 million hectares between 1954 and 1960, and almost $90 \%$ of it could be attributed to the Virgin Lands Program (Durgin 1962). Total sown area became relatively stable after 1960 . The collapse of the Soviet Union in 1992 led to a decrease in cultivated area (Prishchepov et al. 2013).

Fig. 1. A historical view of land change, i.e., changes in cultivated area during the 20th century in Argentina and the former Soviet Union. (A) Data for Argentina includes area sown for 1899-1939 from Tenembaum (1946), area cultivated for 1935-1968 from Rudbeck (1970), and total harvested area for primary crops for 1961-2009 from FAO (2013a). (B) For the Soviet Union, we obtained data on total area sown from Dewdney $(1971,1979)$ for 1913, 1960, 1968, and 1975-1976, from Central Statistical Board of the U.S.S.R Council of Ministers (1957) for 1937 and 1950, from (Volin 1970) for 1921-1929, Jackson (1956, 1962) for 1920, 1932, 1936, 1939 , and 1953-1959, and from Katkoff (1950) for 1940-49; we obtained data on total arable land from Dewdney (1979) for 1976, Committee for the World Atlas of Agriculture (1969) for 1949, 1958, and 1960, from EUROSTAT (1993) for 1980, 1985, and 1987-1990, and arable land and permanent crops for 1961-2008 from FAO (2013a). Note that although the broadscale changes shown by these data are useful, the details may not be caused by poor data quality, because data on variables such as total cultivated area are less reliable compared to the area of major commodities (as in Fig. 3). For example, the 1985 peak in cultivated area for Argentina is an artifact of poor data quality for forage and silage crops.
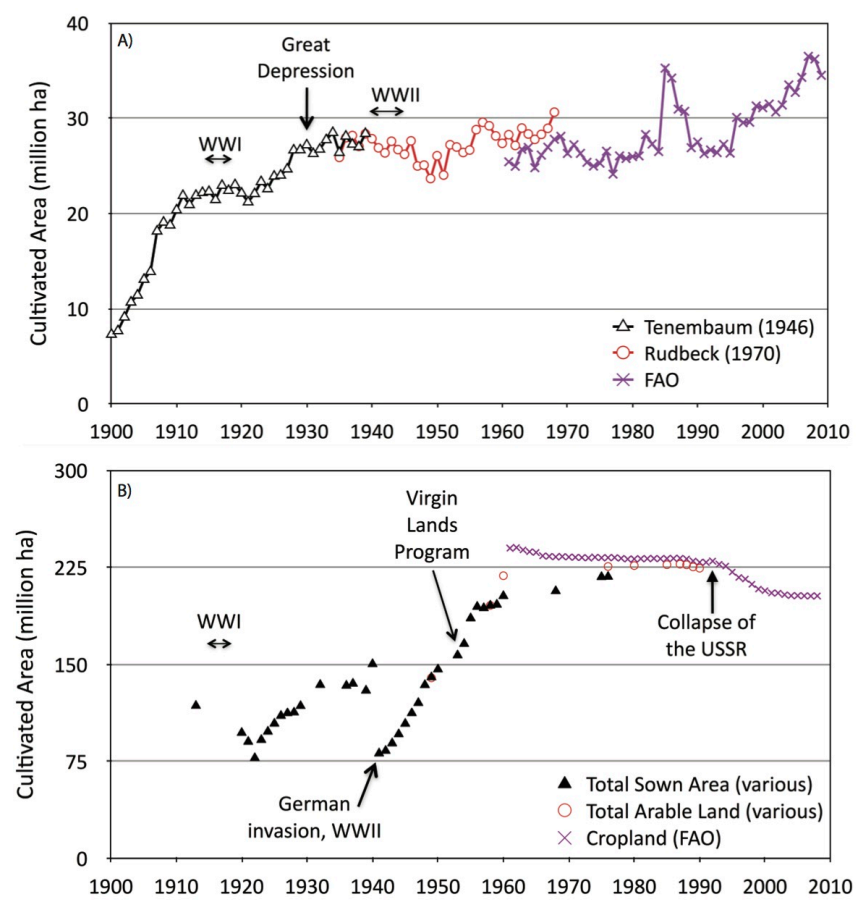
In both of the above cases, land changes occurred due to causes that were likely unpredictable ex ante. In Argentina, the initial trigger for agricultural development was the removal of native Indian encampments from the Pampa by the Argentine army in 1879 , followed by the mass migration and settler occupation (Taylor 1997, Solbrig and Viglizzo 1999), whereas the stagnation was initially caused by World War I and subsequently the Great Depression. In the former Soviet Union, the large increase in cultivated area after 1954 was the result of a national policy (Durgin 1962), whereas the decrease after 1992 was the result of the Soviet collapse (Prishchepov et al. 2013). All of these causes of change were triggered by singular events of history, that are explicable in hindsight but the events driving such change, from war to political upheaval and collapse, would have been difficult to anticipate. However, these unforeseen events led to some of the most rapid and extensive changes in land cover in those regions. A new framework is needed to understand such land-use regime shifts.

\section{FRAMEWORK FOR UNDERSTANDING LAND USE REGIME SHIFTS}

We developed our framework by first defining the system under consideration, its boundaries, and the potential causes of change (Fig. 2).

Fig. 2. Framework for understanding land-use regime shifts. We distinguish between within-regime land-use dynamics and landuse regime shifts. Preconditions are the necessary conditions for a regime shift. Triggers are the immediate cause of the shift. Self-reinforcing processes maintain the new regime in a stable state, resisting a shift back to the old regime. Most land-change studies have focused on studying within-regime dynamics, and not the preconditions, triggers, and self-reinforcing processes governing regime shifts.

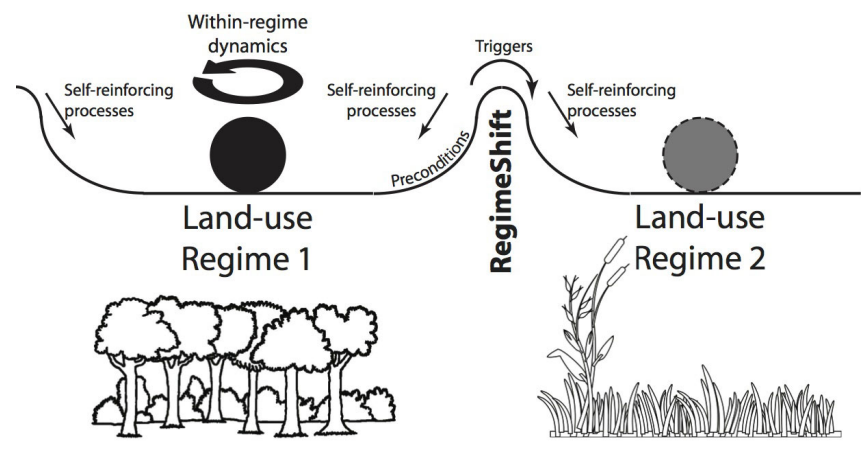

\section{Land-use regime:}

A constellation of enduring land-use dynamics, which may or may not entrain land-cover changes. The regime is place-based, scale-independent, and characterized by the land-use dynamic of interest to the observer. It could, for example, range from smallscale shifting cultivation systems in Peru (Wood et al. 2016), to agroforestry systems in India (Kumar and Nair 2004), and to large-scale oil palm plantations in Indonesia (Koh and Wilcove 2008). We believe that the system boundary has to be drawn by the researcher, depending on the land-use dynamics of interest. This may be an iterative process because the analysis reveals new processes required to be captured, necessitating a redrawing of system boundaries (see Holland 2012 for a discussion of system boundaries). However, as with all open systems, forces outside these boundaries can influence and alter the land-use dynamics.

\section{Land-use regime shift:}

A shift from one dominant land-use regime to another, wherein the enduring land-use dynamics change. This is often, but not always, accompanied by rapid land-cover change. Again, the focus of analysis is on an abrupt or rapid shift in land-use dynamics, following which a new land-use regime with a new set of relatively stable land-use dynamics is established.

We propose that the causes of land-use regime shifts can be understood by characterizing the preconditions and triggers of change, and the self-reinforcing processes that maintain the new state (Fig. 2).

\section{Preconditions:}

Necessary conditions that must be satisfied a priori for a land-use regime shift to occur. They include prevailing product demand and supply conditions; macroeconomic conditions, e.g., currency exchange rates, credit availability, and inflation; and available technology, all of which set the stage for change.

\section{Triggers:}

Particular events (focussing events, using the terminology of Rudel 2013) that are most immediately responsible for the landuse regime shift. In other words, preconditions provide the incentives and/or pressures that make the general environment favorable for a land-use regime to shift, whereas triggers provide the immediate impulse for the shift. Trigger events are highly variable in type and often unforeseeable in nature as well as timing. At least four major groups of triggers exist: (1) new land-use policies, e.g., agricultural development, frontier colonization, credit for agriculture or biofuels, and export promotion; (2) removal of binding constraints, e.g., infrastructure development to provide access and resources such as roads and irrigation, or technological change such as new seeds; (3) demographic change, such as rapid depopulation or in-migration; and, (4) environmental, economic, or social shocks, e.g., fires, hurricanes, droughts, currency devaluations, conflicts, or disease outbreaks.

\section{Self-reinforcing processes:}

Maintain the new regime, establishing conditions that make it difficult to shift back to the old regime. Key self-reinforcing processes include reinvestment in the ascendant land use driven by high financial returns that sustains production and furthers expansion, intensification, or productivity-enhancing technological change (e.g., oil palm plantations), and public investment in developing new infrastructure, processing facilities. Such processes not only entrench a particular land-use regime, with its own dynamic political-economic logic, but they also potentially create the preconditions for a subsequent land-use regime shift.

We illustrate our framework by considering two cases, both addressing rapid land-use change that has threatened tropical forests in Latin America (Tables 1 and 2; Fig. 3).

\section{Case study 1: soy in Brazil}

Brazil became the world's second largest producer and exporter of soy through two major phases of expansion: first in the early 1970 s, and then in the late 1990s (Fig. 3A). Several preconditions 
Table 1. Preconditions, triggers, and self-reinforcing processes for a regime shift from small-scale agriculture (Cerrado 1973) or cattle ranching (Amazon 2001) to soy in Brazil.

\begin{tabular}{|c|c|c|}
\hline Preconditions & Triggers & Self-reinforcing processes \\
\hline $\begin{array}{l}\text { Cerrado }(\sim 1973 \text { shift }) \\
\text { - Development of new tropical soy varieties } \\
\text { (Fearnside 2001, Kaimowitz and Smith } 2001, \\
\text { Schnepf et al. 2001). }\end{array}$ & $\begin{array}{l}\text { - Collapse of anchovies in Peru, a major source of } \\
\text { protein in animal feed, following } 1972 \text { El Niño; } \\
\text { soybeans become a substitute (Fearnside 2001, } \\
\text { Schnepf et al. 2001). } \\
\text { - } 1973 \text { U.S. drought raised international prices; U.S. } \\
\text { response of export embargo further raised soy prices } \\
\text { (McVey et al. 2000, Kaimowitz and Smith 2001). } \\
\text { - Frost in southern Brazil in } 1975 \text { incentivized switch } \\
\text { from labor-intensive coffee to soy (Fearnside 2001). }\end{array}$ & $\begin{array}{l}\text { - Credit subsidies allowing farmers to } \\
\text { adopt agricultural machinery and soil } \\
\text { amendment technologies (Fearnside } \\
\text { 2001, Kaimowitz and Smith 2001). }\end{array}$ \\
\hline $\begin{array}{l}\text { Amazon ( } 2001 \text { shift) } \\
\text { - Incentives for less labor-intense production } \\
\text { systems: (1) } 1964 \text { land statute giving increased } \\
\text { rights to sharecroppers and tenant farmers } \\
\text { causing many to be expelled; and (2) new } \\
\text { minimum wage laws dis-incentivizing labor- } \\
\text { intensive coffee production (Kaimowitz and } \\
\text { Smith 2001). } \\
\text { - Growing demand for soy from China and } \\
\text { gradual increase in the international price of soy } \\
\text { (Fearnside 2001, Schnepf et al. 2001, Nepstad et } \\
\text { al. 2006). }\end{array}$ & $\begin{array}{l}\text { - } 1999 \text { devaluation of Brazilian real raises domestic } \\
\text { prices, triggering supply response (Schnepf et al. } \\
\text { 2001, Richards et al. 2012). } \\
\text { - } 2001 \text { EU ban on animal protein for feed after BSE } \\
\text { outbreak (Nepstad et al. 2006). }\end{array}$ & $\begin{array}{l}\text { - Public investment in improved } \\
\text { transportation infrastructure and private } \\
\text { investment in soy storage and processing } \\
\text { facilities (Nepstad et al. 2006). } \\
\text { - Increased political power of the } \\
\text { soybean lobby enabling further } \\
\text { government support (Kaimowitz and } \\
\text { Smith 2001). }\end{array}$ \\
\hline
\end{tabular}

Fig. 3. Two case studies of land-use regime shifts. (A) The expansion of soybeans in Brazil since 1960; and (B) the growth of aquaculture production in Latin America since 1980. These cases illustrate important regime shifts in the development of these land uses, as well as the significance of events in causing these shifts.
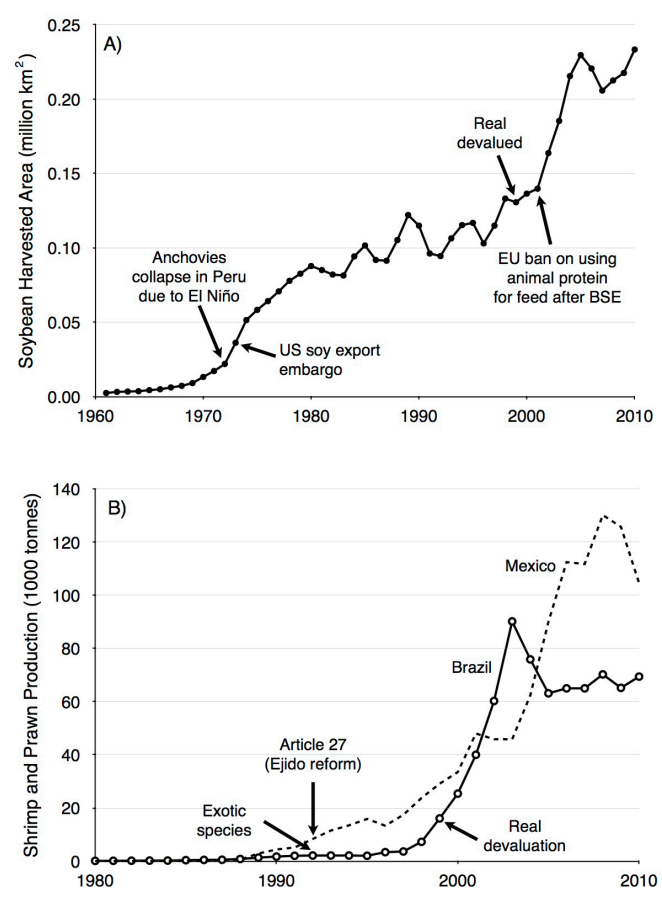

set the stage for soy expansion (Table 1). These include: the development of new soy varieties suited to tropical conditions; incentives for landholders to adopt less labor-intensive systems because of a 1964 land statute providing increasing rights to sharecroppers and a new minimum wage law; the growing demand from China for soy as animal feed; and a gradual increase in the international price of soy (Fearnside 2001, Kaimowitz and Smith 2001, Schnepf et al. 2001, Nepstad et al. 2006).

The triggers of the first phase of soy expansion, in the Cerrado region of Brazil, beginning in 1973 were environmental and politically economic in nature. In 1972, the anchovy catch (a key source of protein in animal feed) off the coast of Peru plummeted from 10.4 million tonnes in the previous year to 4.5 million tonnes, as a result of a strong El Niño event (Caviedes 1975). Soybeans became a substitute for animal feed (Fearnside 2001, Schnepf et al. 2001). Simultaneously, a major drought in the United States decreased global grain production causing a spike in soy prices. In response, driven by the fear of a soy shortage, the U.S. imposed an export embargo on soy in June 1973 (McVey et al. 2000, Kaimowitz and Smith 2001). Europe and Japan, major soy importers, sought reliable alternate sources of animal feed, and Brazil filled the niche aided by Japanese investment (McVey et al. 2000). Heavy frost in 1975 provided an impetus to shift away from labor-intensive coffee production to soy production (Fearnside 2001). Soy-harvested area increased fourfold from 0.02 million $\mathrm{km}^{2}$ in 1972 to 0.09 million $\mathrm{km}^{2}$ in 1980 (FAO 2013b).

Two distinct events triggered the more recent rapid expansion of soy in the Brazilian Amazon. The Brazilian real was floated for the first time in 1999 and devalued rapidly. Although soy prices 
Table 2. Preconditions, triggers, and self-reinforcing processes for a regime shift from artisanal fishing to shrimp production in Latin America.

\begin{tabular}{|c|c|c|}
\hline Preconditions & Triggers & Self-reinforcing processes \\
\hline $\begin{array}{l}\text { General } \\
\text { - High U.S. demand and prices for shrimp in } \\
\text { 1980s (Parks and Bonifaz 1994). } \\
\text { - Availability of abundant coastal land and } \\
\text { wild stocks of shrimp larvae (Schwarz 2005). }\end{array}$ & & $\begin{array}{l}\text { - Development of domestic shrimp hatcheries and } \\
\text { aquafeed firms (DeWalt et al. 2002, Mole and Bunge } \\
\text { 2002, Wurmann et al. 2004). } \\
\text { - High returns on investment in shrimp farming and } \\
\text { reinvestment in the sector (Meltzoff and LiPuma } \\
\text { 1986, Mole and Bunge 2002). } \\
\text { - Tax incentives, subsidies, capital investment, and } \\
\text { export promotion (Mole and Bunge 2002). }\end{array}$ \\
\hline $\begin{array}{l}\text { Mexico } \\
\text { - Long practice of a rudimentary form of } \\
\text { shrimp aquaculture (DeWalt et al. 2002). }\end{array}$ & $\begin{array}{l}\text { - Ejido reform } 1992 \text { (DeWalt et al. 2002, } \\
\text { Wurmann et al. 2004, Luers et al. 2006). }\end{array}$ & $\begin{array}{l}\text { - } 1994 \text { signing of NAFTA and series of fiscal reforms } \\
\text { (DeWalt et al. 2002). }\end{array}$ \\
\hline $\begin{array}{l}\text { - Experimental work with shrimp aquaculture } \\
\text { in the } 1970 \text { s at the University of Sonora } \\
\text { (DeWalt et al. 2002). }\end{array}$ & $\begin{array}{l}\text { - Reform of Fisheries Law 1992; Water Law } \\
\text { 1992; Foreign Investment Law } 1993 \text { (DeWalt et } \\
\text { al. 2002). }\end{array}$ & $\begin{array}{l}\text { - Overcapacity of shrimp fishing fleet (Luers et al. } \\
\text { 2006, Gillett 2008). } \\
\text { - Extended drought causing farmers to switch from } \\
\text { wheat (Luers et al. 2006). }\end{array}$ \\
\hline $\begin{array}{l}\text { Brazil } \\
\text { - Development of good management practices } \\
\text { due to low initial yield of indigenous shrimp } \\
\text { (Mole and Bunge 2002, Wurmann et al. 2004). }\end{array}$ & $\begin{array}{l}\text { - Devaluation of the Brazilian real in } 1999 \\
\text { stimulating entry into international markets } \\
\text { and increase in domestic prices (Mole and } \\
\text { Bunge 2002). }\end{array}$ & $\begin{array}{l}\text { - Protection from white spot syndrome because of } \\
\text { the import ban, slow development of indigenous } \\
\text { shrimp industry, and long distance from Pacific coast } \\
\text { (Mole and Bunge 2002). }\end{array}$ \\
\hline $\begin{array}{l}\text { - Introduction of exotic shrimp (Penaeus } \\
\text { vannamei), with strong results in } 1993 \text { (Mole } \\
\text { and Bunge 2002, Wurmann et al. 2004, Lopes } \\
\text { 2008). }\end{array}$ & $\begin{array}{l}\text { - Collapse of Ecuadorian and other Pacific } \\
\text { coastal farms caused by white spot syndrome } \\
\text { in } 1999 \text { (Mole and Bunge 2002). }\end{array}$ & $\begin{array}{l}\text { - National aquaculture plans to promote investment, } \\
\text { infrastructure, education, and product promotion } \\
\text { (Suplicy 2004). }\end{array}$ \\
\hline
\end{tabular}

fell on the world market between 1997 and 2002, the devalued real made Brazilian exports more competitive in the international market (Schnepf et al. 2001, Richards et al. 2012). This was soon followed by the outbreak of Bovine spongiform encephalopathy (BSE) in Europe. The European Union imposed a ban on the use of animal protein as feed for livestock in 2001, resulting in the further substitution of soy as animal feed (Nepstad et al. 2006). Consumer opposition to genetically modified (GM) crops in the EU resulted in Brazil becoming the world's largest supplier of non-GM soy (Nepstad et al. 2006). The soy-harvested area in Brazil expanded rapidly from 0.14 million $\mathrm{km}^{2}$ in 2001 to 0.23 million $\mathrm{km}^{2}$ in 2005 , and production doubled from $\sim 30$ million tonnes in 1998 to $\sim 60$ million tonnes in 2008 (FAO 2013b).

Although favorable preconditions and key events led to the rapid expansion of soybean production in Brazil, several key selfreinforcing forces were necessary to maintain it. These included credit subsidies allowing farmers to adopt agricultural machinery and soil amendment technologies, massive public expenditure on transportation infrastructure and private investments in soy storage and processing facilities, and increased political power of the soy lobby (Fearnside 2001, Kaimowitz and Smith 2001, Nepstad et al. 2006).

Case study 2: shrimp in Mexico and Brazil

Shrimp farming is a capital-intensive industry responsible for $20-50 \%$ of world mangrove destruction (Primavera 1997). Latin
America and the Caribbean contributed about $15 \%$ of world value in aquaculture during 2001-2002 (Wurmann et al. 2004). Shrimp and prawn production in the region quadrupled between 2000 and 2012 (FAO 2013), with Mexico and Brazil contributing to $30 \%$ of total production in the region in 2012 (FAO 2013). Both producers followed a trajectory of very rapid expansion, beginning from common preconditions (Fig. 3B, Table 2), i.e., high U.S. demand and prices for shrimp in the 1980s (Parks and Bonifaz 1994) and the availability of abundant coastal lands and wild stocks of larvae. Such preconditions were driven and complemented by common self-reinforcing processes, including the development of domestic shrimp hatcheries and aquafeed firms (Wurmann et al. 2004), government provision of tax incentives, sector subsidies and export promotion, and the promise of high returns on investment in shrimp farming (Meltzoff and LiPuma 1986, Mole and Bunge 2002). The triggers and dynamics of expansion, however, were distinct in each exporting country.

\section{Mexico}

A rudimentary form of shrimp aquaculture was long practiced by Mexican fisherman, who trapped shrimp and fish in coastal lagoons (DeWalt et al. 2002). Early experimental work at the Center for Scientific and Technological Research at the University of Sonora provided the foundation for shrimp aquaculture in Mexico, but private investment was precluded by long-standing property regimes that gave "ejidos" (collectives of peasant 
landholders) along the coast exclusive rights to seafood species. Although fisheries cooperatives were set up as early as the 1930s, they lacked the tenure rights of the ejidos and the capital to invest in shrimp farm development (DeWalt et al. 2002).

The main trigger for expansion was a series of policy reforms undertaken by the Salinas government (DeWalt et al. 2002, Luers et al. 2006). In particular, the 1992 amendment of Article 27 of the Mexican Constitution and modification of the General Fisheries Law opened the ejido sector to private investment. These reforms also removed the restrictive access of shrimp capture cultivation to the cooperative/ejido sector (DeWalt et al. 2002, Wurmann et al. 2004, Luers et al. 2006). Aquaculture development was further incentivized by the 1992 Water Law that dropped restrictions on water use for aquaculture, and the 1993 modification of the Foreign Investment Law permitting foreign ownership over aquaculture production. Shrimp production increased from 550 tonnes in 1988, to 15,900 tonnes in 1995, and 130,000 tonnes in 2008 (FAO 2013).

Shrimp farming was further reinforced by the 1994 signing of the North American Free Trade Agreement (NAFTA), which eliminated import duties on inputs for aquaculture and reduced tariffs on feed, and a series of fiscal reforms providing tax incentives for involvement in aquaculture (DeWalt et al. 2002, Luers et al. 2006). Other self-reinforcing processes include the development of ancillary economic activities including hatcheries for postlarvae development, factories for producing balanced feed for shrimp, a network of coastal processing plants (DeWalt et al. 2002), overcapacity in coastal fisheries (Gillett 2008), and a drought that pushed farmers to diversify investment from wheat into aquaculture (Luers et al. 2006).

\section{Brazil}

Shrimp farming began in Brazil during the early 1970s, but productivity was limited by the use of Penaeus japonicus, a lowyielding native shrimp variety that demanded high protein feed but had low survival rates (Mole and Bunge 2002). It was not until the introduction of the exotic shrimp species, Penaeus vannamei, with strong results in 1993, that the Brazilian shrimp industry took off (Mole and Bunge 2002, Wurmann et al. 2004, Lopes 2008). Interestingly, the development of good management practices during the initial experimentation with low yielding indigenous species served as an important precondition that begat, in part, the high yields that came with the introduction of P. vannamei.

As with soy, the key trigger for rapid shrimp development was the devaluation of the real in 1999, which opened the door to international markets and high returns (Mole and Bunge 2002). The Brazilian shrimp market also benefited from the diseasedriven collapse in 1999 of production elsewhere; Brazil was protected from the outbreak of the white spot syndrome virus because of its long distance from the ravaged aquaculture farms on the Pacific coast (Mole and Bunge 2002). Development of the industry was re-enforced through the provision of tax incentives, availability of capital for long-term investments in the sector, the development of domestic shrimp hatcheries and aquafeed companies, and an import ban on shrimp to protect from the white spot syndrome virus (Mole and Bunge 2002). Brazil also developed national plans to promote aquaculture (Suplicy 2004). Output increased rapidly, from 2070 tonnes in 1995 to 90,000 tonnes in 2003 (FAO 2013).

\section{PRIORITIES FOR LAND CHANGE RESEARCH}

Our analytical framework, illustrated by our case studies, suggests that a better understanding of land-use regime shifts would be gained by characterizing preconditions, triggers, and selfreinforcing processes of change (Table 1, Fig. 2). We now generalize from these observations to propose future directions for landchange research.

\section{Need to develop an improved theoretical framework for studying land use regime shifts}

Given the significance of regime shifts in land-use change, the landuse change community needs to develop a better theoretical framework for studying them. In doing so, we can draw from other disciplines in which theoretical development on regime shifts is more advanced.

The literature on regime shifts in ecological and social-ecological systems is probably one of the more developed (Scheffer et al. 2001, Scheffer 2009). Walker et al. (2006) support the proposition that a common theoretical framework could apply to both ecological systems and social systems, and social-ecological systems such as land use, because fundamental ideas of scale, relative rates of change, and thresholds apply to both. The idea of systems having alternate stable states has been well established in ecology, with classic examples from the earliest studies of lake eutrophication (Carpenter 2003). We also learn from the literature that system dynamics are governed by the relationships between slowly changing and rapidly changing variables and that the nature of regime shifts (smooth, abrupt, or discontinuous) is determined by the relationship among these variables (Collie et al. 2004, Biggs et al. 2009). Unfortunately, the stability domain of the system seems to be governed by slowly changing variables, which often go unnoticed and unmonitored. Much research in ecological regime shifts has thus focused on developing indicators of regime shifts (Biggs et al. 2009).

The study of land-use regime shifts could also adopt ideas from frameworks developed to manage and foster socio-technical change such as strategic niche management (SNM) or transition management (TM) for sustainability transitions. Strategic niche management is a framework used to understand the trajectory and evolutionary dynamics of technological change (Schot and Geels 2008). The definition of a (socio)technological regime is broad, including a complex of scientific knowledge, engineering practices, production process technologies, product characteristics, institutions, etc. (Caniëls and Romijn 2008), and techno regimes create economic, technical, cognitive, and social barriers to innovation and use of new technology (Kemp and Hoogma 1998). Over time, niches develop where innovation occurs, sheltered from markets and regulation and sometimes flourish to the point of forcing a technology regime shift. Strategic niche management is a concerted effort to develop protected spaces for the application of new technology (typically sustainable technology). Each regime shift is unique, but certain elements are common to all shifts, e.g., deep inter-relations between technology and environment, specialized applications, systems of related techniques, and social views about technology (Kemp and Hoogma 1998). Transition management is a framework that seeks to foster sustainability transitions (Nill and Kemp 2009, Rotmans and Loorbach 2009). Persistent environmental problems require system innovation. Innovations arise in a Darwinian manner, i.e., variation and selection operate, yet the focus is on managing change in a positive 
direction. Certain principles guide transition management, such as focus on frontrunners, guided variation and selection, radical change in incremental steps, empowering niches, and anticipation (Rotmans and Loorbach 2009).

Ecological research on regime shifts, SNM, and TM offer useful insights for land-use change research. However, one needs to be careful when adapting these frameworks for land-use research. There are some fundamental differences in the objectives of the different frameworks. Ecological research is typically focused on avoiding the undesirable outcomes of regime shifts (e.g., lake eutrophication). Strategic niche management and TM are aimed at managing and fostering technological change or sustainability transitions. Land-use change research, on the other hand, is focused on understanding and anticipating land-use change rather than managing or avoiding it. Nevertheless, future landuse research should consider borrowing from these and other frameworks in developing new theory to understand land-use regime shifts.

\section{Need for a land use regime change database}

A major effort is required to compile historical case studies of land-use change at varying levels of analysis, ranging from community-to-regional-to-national scale and at multiple temporal scales, i.e., the long historical and the more recent changes. Particular attention in cataloguing and analyzing the case studies would be given to the states and rates of land change and if the changes are caused by regime shifts, also the preconditions, triggers, and self-reinforcing processes of change. Well-known cases of land-use change merit revisiting, and new cases studied need to go beyond describing the changes occurred to specifying the underlying processes of change as guided by our analytic framework. A land-use change database, similar perhaps to that recently released by the Stockholm Resilience Centre, that documents large-scale persistence change in social-ecological systems (http://www.regimeshifts.org), which as yet contains few cases of anthropogenic-driven land change, would be a valuable resource not only for land-change scientists, but also for ecologists and other natural scientists studying links between changes in the land and other biophysical systems. A land-use change database would provide the foundation for scientists to pursue several questions that are central to future research on land-use regimes shifts.

\section{How important are regime shifts in global land change?}

Underpinning our analytical framework is the assertion that important land changes occur through land-use regime shifts, as illustrated by our case studies of soy and shrimp in Latin America. Elsewhere, Müller et al. (2014) made a similar case, offering instances of smaller-scale land-use regime shifts in Southeast Asia. But how common and significant are land-use regime shifts? What is the contribution to total land change of gradual withinregime change versus regime shifts? Under what circumstances and conditions do land-use regime shifts result in major landcover changes? These are empirical questions that could be addressed by analyzing the proposed land-use change database.

\section{Are land-use regime shifts scale independent?}

In our viewpoint, there are two aspects to the scale independence question. The first is whether regime shifts are constrained to certain spatial or temporal scales, or if they occur at multiple scales. We believe that they do occur at multiple scales as evidenced by the smaller community level studies of Müller et al. (2014) and our national-level examples. The development of a land-use regime shifts database will allow us to test scale independence more rigorously.

The second aspect of this question is whether a land-use change to be categorized as a regime shift is dependent on the scale of analysis (i.e., appears as a regime shift at one scale but not at a larger scale). As an example, let's imagine a farm that uses a cornsoy rotation. If one looks only at the farm over a two-year period it might appear that corn switching to soy is a regime shift. But looking over a longer period of time or over a large scale, it will be clear that this is not a regime shift. Our response is that the initial analysis of a corn-soy regime shift at the two-year farm level was flawed and had an inadequate understanding of the land-use dynamics, and was, instead, focused on only the shifting land cover. An analysis of the land-use dynamics, even at the farm level, would have clearly identified that the farm uses a crop rotation system. In other words, process rather than pattern is the key to understanding land-use change. Thus, our preliminary hypothesis is that land-use regime shifts are scale independent, but we recognize that this question requires future investigation.

\section{How can land-use regimes shifts be usefully predicted?}

The ecological literature suggests that regime shifts are extremely challenging to predict (Biggs et al. 2009, Scheffer et al. 2009). Accordingly, scientists search for early warning indicators that foreshadow an imminent shift. It appears that regime shifts are accompanied by a phenomenon knowing as "critical slowing down" (Scheffer et al. 2009). Successful leading indicators of regime shifts, when time-series data are available, include increases in variance, shift of variance to lower frequencies, changing skewness, or decreases in response rate to disturbances (Carpenter et al. 2008, Biggs et al. 2009, Scheffer et al. 2009). In the absence of time-series data, some studies have suggested that increases in spatial variance, spatial correlation, and changes in spatial skewness can be key indicators (Guttal and Jayaprakash 2009, Dakos et al. 2010). Biggs et al. (2009) found, however, that large changes in indicators often occur only once a regime shift is already underway and the authors suggest a shift in focus to defining critical indicator levels, rather than detecting change in indicators. This growing body of research on regime shifts in social-ecological systems and their predictions has considerable potential for informing land-use change research.

Two important considerations arise when applying these principles from ecology to land-use systems. First, land-use monitoring systems will need to be developed to provide rich time series or spatial data required to develop early warning indicators. The types of data that could be useful include: high-spatial or high-temporal resolution satellite data on land-cover properties, time-series data on commodity prices, trade flows, and other economic indicators. Second, unlike ecological systems (Folke et al. 2004, Biggs et al. 2009), land-use regime shifts are not inherently undesirable, although some consequences, such as biodiversity loss or displacement of populations, may be. Therefore, rather than seeking early warning indicators per se, it is perhaps more important to understand whether a particular land-use regime may be susceptible to a future shift. Such an understanding of how systems are more or less vulnerable to regime shifts that might be triggered by external forces will enable us to develop improved scenarios of future land-use change. 


\section{Preliminary considerations for a new theoretical framework of} land-use regime shifts

The development of a new theory of land-use regime shifts will first have to contend with the selection of appropriate variables. Researchers will need to define state variables that depict the state of a system at any point in time. To take our Brazilian soy example, appropriate state variables may be cattle production and soy production. Key economic variables of interest may be commodity prices, international currency exchange rates, and input costs, while land tenure is likely to be an important social variable.

Resilience theory suggests that systems are vulnerable to regime shifts when they have interactions between variables that operate at different scales (fast vs. slow or small vs. large; Walker et al. 2006). Land-use managers and scholars are typically concerned with the fast variables and those directly at their scale of study or influence, while the slowly changing variables (or those at larger scales) often go unnoticed (Biggs et al. 2009). Although the different contributions of slow and fast variables to land change have been recognized (Geist et al. 2006), their connection to landuse regime shifts requires further theoretical development. In particular, slow variables, which govern the stability domain of the system as discussed earlier, need to identified and monitored in land-use systems. We hypothesize that changes in land holdings (consolidation or division) or land-use intensification are examples of slow variables. The increasing demand for a commodity (e.g., soy from China) may be a key slow variable, although, depending on the boundary definition, may be exogenous to the system.

Unlike geophysical systems or ecological systems, we do not think that land-use systems are likely to exhibit bimodality or alternate stable states in practice, because of the continuous exogenous pressure from growing human populations on land-use systems. For the same reason, we believe that although land-use regime shifts are reversible in principle, they may not be in practice unless the human pressure on the system is removed and given enough time for system recovery. Forest transitions are a good example of the reversal of land-use change (Rudel et al. 2005). Thus, although the existence of alternate stable states is a key indicator of regime shifts, it may be challenging, in practice, to empirically identify these. Further, a recent paper showed that intrinsic stochasticity could dramatically alter the nature of the phase transitions (Villa Martín et al. 2015), further exacerbating the challenge. The development and analysis of a land-use regime shift database, discussed earlier, would be a first step in identifying land-use regime shifts in practice.

A related theoretical construct in land-use science is proximate versus ultimate causes of change, and mediating factors (e.g., institutions, gender, ethnicity) that govern the interplay between variables of change (Geist et al. 2006). Proximate drivers are the direct influences on land-use change (e.g., deforestation for cattle ranching), whereas ultimate drivers are distant, longer-term processes (e.g., increased world demand for meat). In an increasingly globalized world, trade, land teleconnections, and land grabs connect consumers (often in urban areas) and producers in distant parts of the world (Seto et al. 2012, Garrett et al. 2013, MacDonald et al. 2015, Borras and Franco 2012). In this context, the identification of slow variables governing the regime-shift dynamic becomes increasingly challenging because these may be distant and unnoticed.

An improved understanding of the interactions between proximate and ultimate drivers of land-use change, and slow and fast variables of change, will greatly improve our ability to characterize the vulnerability of land-use systems to regime shifts.

\section{CONCLUSIONS}

We believe that land-change research needs to focus on understanding land-use regime shifts. In developing the case studies, we found few studies of that critical period when a major change in land use occurs, or analyses of the drivers of such change (but see Luers et al. 2006, Richards et al. 2012, Müller et al. 2014). New attention to the conditions that govern the critical points of change can greatly enhance our ability to anticipate future land-use change. A critical next step may be a comprehensive review of existing case studies of land-use change to identify regime shifts and their potential causes. Advances in the study of regime shifts in other disciplines guide us in developing a new research agenda for land-change science (Filatova et al., Friis et al. 2016).

In closing, we believe that land-change research, even if fuller attention is given to regime shifts, is unlikely to be able to offer the accurate predictions of decadal-to-centennial time-scale landcover changes that are so much in demand by the global change science community. As in climate science and ecosystem science, a scenarios approach is a useful strategy for projecting future changes in the land (Carpenter et al. 2006, Alcamo et al. 2009, Moss et al. 2010). Nonetheless, closer study of land-use regime shifts promises to advance significantly our understanding of land use and land-cover dynamics that drive global change.

Responses to this article can be read online at: http://www.ecologyandsociety.org/issues/responses. $\mathrm{php} / 8370$

\section{Acknowledgments:}

Earlier versions of this work were presented at the American Geophysical Union Fall Meeting in 2007 and the First Global Land Project Open Science Conference in 2010. We would like to thank participants at these meetings for their valuable comments, and particularly B.L. Turner II, J. Foley, T. Rudel, and S. Carpenter for their encouragement, valuable comments on an earlier version of the manuscript, and for pointing us to pertinent literature. The insightful comments and suggestions of the Associate Editor, Kasper Kok, and two anonymous reviewers are gratefully acknowledged.

\section{LITERATURE CITED}

Alcamo, J., K. Kok, G. Busch, J. Priess, B. Eickhout, M. Rounsevell, D. S. Rothman, and M. Heistermann. 2009. Searching for the future of land: scenarios from the local to global scale. Pages 67-103 in J. Alcamo, editor. Environmental futures: the practice of environmental scenario analysis. Elsevier, Amsterdam, the Netherlands. http://dx.doi.org/10.1007/3-540-32202-7_6 
Alcamo, J., D. van Vuuren, C. Ringler, W. Cramer, T. Masui, J. Alder, and K. Schulze. 2005. Changes in nature's balance sheet: model-based estimates of future worldwide ecosystem services. Ecology and Society 10(2):19. [online] URL: http://www. ecologyandsociety.org/vol10/iss2/art19/

Biggs, R., S. R. Carpenter, and W. A. Brock. 2009. Turning back from the brink: detecting an impending regime shift in time to avert it. Proceedings of the National Academy of Sciences 106 (3):826-831. http://dx.doi.org/10.1073/pnas.0811729106

Borras, Jr., S. M., and J. C. Franco. 2012. Global land grabbing and trajectories of agrarian change: a preliminary analysis. Journal of Agrarian Change 12:34-59. http://dx.doi.org/10.1111/ j.1471-0366.2011.00339.x

Caniëls, M. C. J., and H. A. Romijn. 2008. Strategic niche management: towards a policy tool for sustainable development. Technology Analysis and Strategic Management 20(2):245-266. http://dx.doi.org/10.1080/09537320701711264

Carpenter, S. R. 2003. Regime shifts in lake ecosystems: pattern and variation. Excellence in Ecology Series, Vol. 15. Ecology Institute, Oldendorf, Germany.

Carpenter, S. R., E. M. Bennett, and G. D. Peterson. 2006. Scenarios for ecosystem services: an overview. Ecology and Society 11(1):29. [online] URL: http://www.ecologyandsociety. org/vol11/iss1/art29/

Carpenter, S. R., W. A. Brock, J. J. Cole, J. F. Kitchell, and M. L. Pace. 2008. Leading indicators of trophic cascades. Ecology Letters 11(2):128-138. http://dx.doi.org/10.1111/j.1461-0248.2007.01131. $\underline{x}$

Caviedes, C. N. 1975. El Niño 1972: its climatic, ecological, human, and economic implications. Geographical Review 65 (4):493-509. http://dx.doi.org/10.2307/213747

Central Statistical Board of the U.S.S.R. Council of Ministers. 1957. National economy of the U.S.S.R: statistical returns. Foreign Languages Publishing House, Moscow, Russia.

Collie, J. S., K. Richardson, and J. H. Steele. 2004. Regime shifts: can ecological theory illuminate the mechanisms? Progress in Oceanography 60(2-4):281-302. http://dx.doi.org/10.1016/j. pocean.2004.02.013

Committee for the World Atlas of Agriculture. 1969. World atlas of agriculture. Volume 1. Europe, U.S.S.R., Asia Minor. Instituto Geografico De Agostino, Novara, Italy.

Cronon, W. 1983. Changes in the land: Indians, colonists, and the ecology of New England. Hill and Wang, New York, New York, USA.

Dakos, V., E. H. van Nes, R. Donangelo, H. Fort, and M. Scheffer. 2010. Spatial correlation as leading indicator of catastrophic shifts. Theoretical Ecology 3(3):163-174. http://dx.doi.org/10.1007/ s12080-009-0060-6

Dean, W. 1995. With broadax and firebrand: the destruction of the Brazilian Atlantic forest. University of California Press, Berkeley, California, USA.

DeWalt, B. R., J. R. R. Zavala, L. Noriega, and R. E. González. 2002. Shrimp aquaculture, the people and the environment in
Coastal Mexico. Report prepared under the World Bank, NACA, WWF and FAO Consortium Program on Shrimp Farming and the Environment. Work in Progress for Public Discussion. FAO, Rome, Italy.

Dewdney, J. C. 1971. A geography of the Soviet Union. Second Edition. Pergamon, Oxford, England.

Dewdney, J. C. 1979. A geography of the Soviet Union. Third Edition. Pergamon, Oxford, England.

Durgin, F. A., Jr. 1962. The Virgin lands programme 1954-1960. Soviet Studies 13(3):255-280.

Eurostat. 1993. Country profile: the Soviet Union, 1980 to 1991. Survey of the final years. Eurostat, Statistical office of the European communities, Luxembourg City, Luxembourg.

Fearnside, P. M. 2001. Soybean cultivation as a threat to the environment in Brazil. Environmental Conservation 28(1):23-38. http://dx.doi.org/10.1017/s0376892901000030

Fearnside, P. M. 2005. Deforestation in Brazilian Amazonia: history, rates, and consequences. Conservation Biology 19 (3):680-688. http://dx.doi.org/10.1111/j.1523-1739.2005.00697.x

Feddema, J. J., K. W. Oleson, G. B. Bonan, L. O. Mearns, L. E. Buja, G. A. Meehl, and W. M. Washington. 2005. The importance of land-cover change in simulating future climates. Science 310 (5754):1674-1678. http://dx.doi.org/10.1126/science.1118160

Filatova, T., J. G. Polhill, and S. van Ewijk. 2016. Regime shifts in coupled socio-environmental systems: review of modelling challenges and approaches. Environmental Modelling and Software 75:333-347. http://dx.doi.org/10.1016/j.envsoft.2015.04.003

Foley, J. A., R. DeFries, G. P. Asner, C. Barford, G. Bonan, S. R. Carpenter, F. S. Chapin, M. T. Coe, G. C. Daily, H. K. Gibbs, J. H. Helkowski, T. Holloway, E. A. Howard, C. J. Kucharik, C. Monfreda, J. A. Patz, I. C. Prentice, N. Ramankutty, and P. K. Snyder. 2005. Global consequences of land use. Science 309 (5734):570-574. http://dx.doi.org/10.1126/science.1111772

Folke, C., S. Carpenter, B. Walker, M. Scheffer, T. Elmqvist, L. Gunderson, and C. S. Holling. 2004. Regime shifts, resilience, and biodiversity in ecosystem management. Annual Review of Ecology, Evolution, and Systematics 35(1):557-581. http://dx.doi. org/10.1146/annurev.ecolsys.35.021103.105711

Food and Agriculture Organization of the United Nations (FAO). 2013a. FAOSTAT database. The Food and Agriculture Organization of the United Nations, Rome, Italy. [online] URL: http://faostat.fao.org

Food and Agriculture Organization of the United Nations (FAO). 2013b. Global aquaculture production. Food and Agriculture Organization of the United Nations, Rome, Italy. [online] URL: http://www.fao.org/fishery/statistics/global-aquaculture-production/ $\underline{\text { en }}$

Friis, C., J. Ø. Nielsen, I. Otero, H. Haberl, J. Niewöhner, and P. Hostert. 2016. From teleconnection to telecoupling: taking stock of an emerging framework in land system science. Journal of Land Use Science 11:131-153. http://dx.doi.org/10.1080/1747423x.2015.1096423

Gadgil, M., and R. Guha. 1993. This fissured land: an ecological history of India. University of California Press, Berkeley, 
California, USA. http://dx.doi.org/10.1093/acprof: oso/9780198077442.001.0001

Garrett, R. D., X. Rueda, and E. F. Lambin. 2013. Globalization's unexpected impact on soybean production in South America: linkages between preferences for non-genetically modified crops, eco-certifications, and land use. Environmental Research Letters 8(4):044055. http://dx.doi.org/10.1088/1748-9326/8/4/044055

Geist, H. J., W. McConnell, E. F. Lambin, E. Moran, D. Alves, and T. Rudel. 2006. Causes and trajectories of land-use/cover change. Pages 41-70 in E. F. Lambin and H. J. Geist, editors. Land use and land cover change: local processes, global impacts. Springer Verlag, New York, New York, USA. http://dx.doi. org/10.1007/3-540-32202-7_3

Gillett, R. 2008. Global study of shrimp fisheries. FAO fisheries technical paper 475. Food and Agriculture Organization of the United Nations, Rome, Italy. [online] URL: http://www.fao.org/ docrep/011/i0300e/i0300e00.HTM

Grau, H. R., T. M. Aide, and N. I. Gasparri. 2005. Globalization and soybean expansion into semiarid ecosystems of Argentina. Ambio 34(3):265-266. http://dx.doi.org/10.1579/0044-7447-34.3.265

Guttal, V., and C. Jayaprakash. 2009. Spatial variance and spatial skewness: leading indicators of regime shifts in spatial ecological systems. Theoretical Ecology 2(1):3-12. http://dx.doi.org/10.1007/ s12080-008-0033-1

Holland, J. H. 2012. Signals and boundaries: building blocks for complex adaptive systems. MIT Press, Cambridge, Massachusetts, USA.

Jackson, W. A. D. 1956. The virgin and idle lands of Western Siberia and Northern Kazakhstan: a geographical appraisal. Geographical Review 46(1):1-19. http://dx.doi.org/10.2307/211959

Jackson, W. A. D. 1962. The virgin and idle lands program reappraised. Annals of the Association of American Geographers 52(1):69-79. http://dx.doi.org/10.1111/j.1467-8306.1962.tb00396. $\underline{\mathrm{x}}$

Kaimowitz, D., and J. Smith. 2001. Soybean technology and the loss of natural vegetation in Brazil and Bolivia. Pages 195-211 in A. Angelsen and D. Kaimowitz, editors. Agricultural technologies and tropical deforestation. $\mathrm{CAB}$ International, Oxfordshire, UK. http://dx.doi.org/10.1079/9780851994512.0195

Katkoff, V. 1950. Soviet grain production: 1940-1950. Land Economics 26(3):207-221. http://dx.doi.org/10.2307/3159589

Kemp, R., J. Shot, and R. Hoogma. 1998. Regime shifts to sustainability through processes of niche formation: the approach of strategic niche management. Technology Analysis and Strategic Management 10(2):175-195. http://dx.doi.org/10.1080/09537329$\underline{808524310}$

Keys, E., and W. J. McConnell. 2005. Global change and the intensification of agriculture in the tropics. Global Environmental Change 15(320-337. http://dx.doi.org/10.1016/j.gloenvcha.2005.04.004

Klein Goldewijk, K. 2001. Estimating global land use change over the past 300 years: the HYDE Database. Global Biogeochemical Cycles 15(2):417-433.
Koh, L. P., and D. S. Wilcove. 2008. Is oil palm agriculture really destroying tropical biodiversity? Conservation Letters 1(2):60-64.

Kongsager, R., and A. Reenberg. 2012. Contemporary land-use transitions: the global oil palm expansion. Global Land Project Report No. 4. Global Land Project, Copenhagen, Denmark. [online] URL: http://www.globallandproject.org/arquivos/Kongsager, _R_and_Reenberg_A_(2012)_Contemporary_land_use transitions The global oil palm.pdf

Kumar, B. M., and P. K. R. Nair. 2004. The enigma of tropical homegardens. Agroforestry Systems 61-62(1-3):135-152.

Lambin, E. F., and H. J. Geist, editors. 2006. Land-use and landcover change: local processes and global impacts. Springer-Verlag, Berlin, Germany. http://dx.doi.org/10.1007/3-540-32202-7

Lambin, E. F., and P. Meyfroidt. 2010. Land use transitions: socio-ecological feedback versus socio-economic change. Land Use Policy 27(2):108-118. http://dx.doi.org/10.1016/j. landusepol.2009.09.003

Lopes, P. F. M. 2008. Extracted and farmed shrimp fisheries in Brazil: economic, environmental and social consequences of exploitation. Environment, Development and Sustainability 10 (5):639-655. http://dx.doi.org/10.1007/s10668-008-9148-1

Lüdeke, M. K. B., G. Petschel-Held, and H.-J. Schellnhuber. 2004. Syndromes of global change: the first panoramic view. GAIA Ecological Perspectives for Science and Society 13(1):42-49.

Luers, A. L., R. L. Naylor, and P. A. Matson. 2006. A case study of land reform and coastal land transformation in southern Sonora, Mexico. Land Use Policy 23(4):436-447. http://dx.doi. org/10.1016/j.landusepol.2005.04.002

MacDonald, G. K., K. A. Brauman, S. P. Sun, K. M. Carlson, E. S. Cassidy, J. S. Gerber, and P. C. West. 2015. Rethinking agricultural trade relationships in an era of globalization. Bioscience 65(3):275-289. http://dx.doi.org/10.1093/biosci/biu225

McVey, M., P. Baumel, and B. Wisner. 2000. Brazilian soybeans what is the potential? Ag Decision Maker newsletter. Iowa State University, Ames, Iowa, USA. [online] URL: https://www. extension.iastate.edu/agdm/articles/others/McVOct00.html

Meltzoff, S. K., and E. LiPuma. 1986. The social and political economy of coastal zone management: shrimp mariculture in Ecuador. Coastal Zone Management Journal 14(4):349-380. http://dx.doi.org/10.1080/08920758609362009

Mole, P., and J. Bunge. 2002. Shrimp farming in Brazil: an industry overview. Report prepared under the World Bank, NACA, WWF and FAO Consortium Program on Shrimp Farming and the Environment. Work in progress for public discussion. FAO, Rome, Italy.

Moss, R. H., J. A. Edmonds, K. A. Hibbard, M. R. Manning, S. K. Rose, D. P. van Vuuren, T. R. Carter, S. Emori, M. Kainuma, T. Kram, G. A. Meehl, J. F. B. Mitchell, N. Nakicenovic, K. Riahi, S. J. Smith, R. J. Stouffer, A. M. Thomson, J. P. Weyant, and T. J. Wilbanks. 2010. The next generation of scenarios for climate change research and assessment. Nature 463(7282):747-756. http://dx.doi.org/10.1038/nature08823 
Müller, D., and D. K. Munroe. 2014. Current and future challenges in land-use science. Journal of Land Use Science 9 (2):133-142. http://dx.doi.org/10.1080/1747423x.2014.883731

Müller, D., Z. Sun, T. Vongvisouk, D. Pflugmacher, J. Xu, and O. Mertz. 2014. Regime shifts limit the predictability of land-system change. Global Environmental Change 28:75-83. http://dx.doi. org/10.1016/j.gloenvcha.2014.06.003

Nelson, E., G. Mendoza, J. Regetz, S. Polasky, H. Tallis, D. Cameron, K. M. A. Chan, G. C. Daily, J. Goldstein, P. M. Kareiva, E. Lonsdorf, R. Naidoo, T. H. Ricketts, and M. Shaw. 2009. Modeling multiple ecosystem services, biodiversity conservation, commodity production, and tradeoffs at landscape scales. Frontiers in Ecology and the Environment 7(1):4-11. http://dx.doi. org/10.1890/080023

Nepstad, D., C. M. Stickler, and O. T. Almeida. 2006. Globalization of the Amazon soy and beef industries: opportunities for conservation. Conservation Biology 20 (6):1595-1603. http://dx.doi.org/10.1111/j.1523-1739.2006.00510. $\underline{\mathrm{X}}$

Nill, J., and R. Kemp. 2009. Evolutionary approaches for sustainable innovation policies: from niche to paradigm. Research Policy 38(668-680. http://dx.doi.org/10.1016/j.respol.2009.01.011

Parks, P. J., and M. Bonifaz. 1994. Nonsustainable use of renewable resources: mangrove deforestation and mariculture in Ecuador. Marine Resource Economics 9(1-8. http://dx.doi. org/10.1086/mre.9.1.42629577

Pontius, R., Jr., W. Boersma, J.-C. Castella, K. Clarke, T. de Nijs, C. Dietzel, Z. Duan, E. Fotsing, N. Goldstein, K. Kok, E. Koomen, C. Lippitt, W. McConnell, A. Mohd Sood, B. Pijanowski, S. Pithadia, S. Sweeney, T. Trung, A. T. Veldkamp, and P. Verburg. 2008. Comparing the input, output, and validation maps for several models of land change. Annals of Regional Science 42(1):11-37. http://dx.doi.org/10.1007/ s00168-007-0138-2

Primavera, J. H. 1997. Socio-economic impacts of shrimp culture. Aquaculture Research 28(10):815-827.

Prishchepov, A. V., D. Müller, M. Dubinin, M. Baumann, and V. C. Radeloff. 2013. Determinants of agricultural land abandonment in post-Soviet European Russia. Land Use Policy 30(1):873-884. http://dx.doi.org/10.1016/j.landusepol.2012.06.011

Ramankutty, N. 2007. Rates And patterns of historical land-use change: lessons for modeling the future. Transactions of the American Geophysical Union 88(52).

Ramankutty, N., O. Coomes, and H. Cray. 2010. Land use change as a punctuated-equilibrium process. Proceedings of the Global Land Project open science meeting 2010, Oct 17-19, Tempe, Arizona, USA. Global Land Project, Bern, Swizterland.

Ramankutty, N., and J. A. Foley. 1999. Estimating historical changes in global land cover: croplands from 1700 to 1992. Global Biogeochemical Cycles 13:997-1027. http://dx.doi. org/10.1029/1999GB900046

Richards, P. D., R. J. Myers, S. M. Swinton, and R. T. Walker. 2012. Exchange rates, soybean supply response, and deforestation in South America. Global Environmental Change 22(2):454-462. http://dx.doi.org/10.1016/j.gloenvcha.2012.01.004
Rotmans, J., and D. Loorbach. 2009. Complexity and transition management. Journal of Industrial Ecology 13(2):184-196. http:// dx.doi.org/10.1111/j.1530-9290.2009.00116.x

Rounsevell, M. D. A., B. Pedroli, K.-H. Erb, M. Gramberger, A. G. Busck, H. Haberl, S. Kristensen, T. Kuemmerle, S. Lavorel, M. Lindner, H. Lotze-Campen, M. J. Metzger, D. Murray-Rust, A. Popp, M. Pérez-Soba, A. Reenberg, A. Vadineanu, P. H. Verburg, and B. Wolfslehner. 2012. Challenges for land system science. Land Use Policy 29(4):899-910. http://dx.doi.org/10.1016/ j.landusepol.2012.01.007

Rudbeck, J. P. 1970. Grain production and marketing in Argentina. FAS-M222. U.S. Department of Agriculture, Foreign Agricultural Service, Washington, D.C., USA.

Rudel, T. K. 2013. Defensive environmentalists and the dynamics of global reform. Cambridge University Press, New York, New York, USA. http://dx.doi.org/10.1017/cbo9781139343800

Rudel, T. K., O. T. Coomes, E. Moran, F. Achard, A. Angelsen, J. Xu, and E. Lambin. 2005. Forest transitions: towards a global understanding of land use change. Global Environmental ChangeHuman and Policy Dimensions 15(1):23-31. [online] URL: http:// www.iatp.org/documents/forest-transitions-towards-a-globalunderstanding-of-land-use-change

Scheffer, M. 2009. Critical transitions in nature and society. Princeton University Press, Princeton, New Jersey, USA.

Scheffer, M., J. Bascompte, W. A. Brock, V. Brovkin, S. R. Carpenter, V. Dakos, H. Held, E. H. van Nes, M. Rietkerk, and G. Sugihara. 2009. Early-warning signals for critical transitions. Nature 461:53-59. http://dx.doi.org/10.1038/nature08227

Scheffer, M., S. Carpenter, J. A. Foley, C. Folke, and B. Walker. 2001. Catastrophic shifts in ecosystems. Nature 413:591-596. http://dx.doi.org/10.1038/35098000

Schnepf, R. D., E. Dohlman, and C. Bolling. 2001. Agriculture in Brazil and Argentina: developments and prospects for major field crops. Market and Trade Economics Division, Economic Research Service, U.S. Department of Agriculture, Washington D.C., USA. [online] URL: http://www.ers.usda.gov/media/295731/ $\underline{\text { wrs0013 } 1 \text {.pdf }}$

Schot, J., and F. W. Geels. 2008. Strategic niche management and sustainable innovation journeys: theory, findings, research agenda, and policy. Technology Analysis and Strategic Management 20(5):537-554. http://dx.doi.org/10.1080/09537320$\underline{802292651}$

Schwarz, L. 2012. National aquaculture sector overview fact sheets: Ecuador. FAO Fisheries and Aquaculture Department, Rome, Italy. [online] URL: http://www.fao.org/fishery/countrysector/ naso ecuador/en

Seto, K. C., A. Reenberg, C. G. Boone, M. Fragkias, D. Haase, T. Langanke, P. Marcotullio, D. K. Munroe, B. Olah, and D. Simon. 2012. Urban land teleconnections and sustainability. Proceedings of the National Academy of Sciences 109 (20):7687-7692. http://dx.doi.org/10.1073/pnas.1117622109

Smith, J. N. 1968. Argentine agriculture: trends in production and world competition. Economic Research Service, U.S. Department of Agriculture, Washington, D.C., USA. [online] URL: http:// babel. hathitrust.org/cgi/pt?id=uiug. 30112018972296; view=1up;seq=1 
Solbrig, O. T., and E. F. Viglizzo. 1999. Sustainable farming in the Argentine pampas: history, society, economy, and ecology. Paper No. 99/00-1, DRCLAS (Working papers on Latin America). Harvard University, Cambridge, Massachusetts, USA. [online] URL: http://citeseerx.ist.psu.edu/viewdoc/download?

$\underline{\text { doi }=10.1 .1 .202 .7923 \& r e p=r e p 1 \& t y p e ~}=$ pdf

Suplicy, F. M. 2004. National aquaculture sector overview fact sheets: Brazil. FAO Fisheries and Aquaculture Department, Rome, Italy. [online] URL: http://www.fao.org/fishery/countrysector/ naso brazil/en

Taylor, A. M. 1997. Peopling the Pampa: on the impact of mass migration to the River Plate, 1870-1914. Explorations in Economic History 34:100-132.

Tenembaum, J. L. 1946. Orientación económica de la agricultura argentina. Losada, Buenos Aires, Argentina.

Veldkamp, A., and E. F. Lambin. 2001. Predicting land-use change. Agriculture, Ecosystems and Environment 85(1-3):1-6. http://dx.doi.org/10.1016/s0167-8809(01)00199-2

Villa Martín, P., J. A. Bonachela, S. A. Levin, and M. A. Muñoz. 2015. Eluding catastrophic shifts. Proceedings of the National Academy of Sciences 112(15):E1828-E1836. http://dx.doi. org/10.1073/pnas. 1414708112

Volin, L. 1970. A century of Russian agriculture: from Alexander II to Khruschev. Harvard University Press, Cambridge, Massachusetts, USA.

Walker, B. H., L. H. Gunderson, A. P. Kinzig, C. Folke, S. R. Carpenter, and L. Schultz. 2006. A handful of heuristics and some propositions for understanding resilience in social-ecological systems. Ecology and Society 11(1):13. [online] URL: http://www. ecologyandsociety.org/vol11/iss1/art13/

Wood, S. L. R., J. M. Rhemtulla, and O. T. Coomes. 2016. Intensification of tropical fallow-based agriculture: trading-off ecosystem services for economic gain in shifting cultivation landscapes? Agriculture, Ecosystems and Environment 215(47-56). http://dx.doi.org/10.1016/j.agee.2015.09.005

Worster, D. 1979. Dust bowl: the Southern Plains in the 1930s. Oxford University Press, New York, New York, USA.

Wurmann, C. G., R. M. Madrid, and A. M. Brugger. 2004. Shrimp farming in Latin America: current status, opportunities, challenges and strategies for sustainable development. Aquaculture Economics and Management 8(3-4):117-141. http:// dx.doi.org/10.1080/13657300409380358 